\title{
DE EILANDJES COMMERRUST, CLAARBEEK, SCHOOTEROOG EN VLAMING.
}

Op bladzijde 306 van het Tiende deel (2de en 3 de stuk) van de Bijdragen, gaven wij op, dat ons onbekend was gebleven de tijd wanneer en door wien deze eilandjes zijn benoemd. Sedert is door ons eene aanteekening gevonden, waaruit blijkt dat de bovengenoemde namen zijn gegeven door den Schipper en Wimpelvoerder Pieter Verley, die met de schepen Commerrust, Claarbeek, Schooteroog en de sloep Vlaming, in 1727 van Ternate vertrok op een kruistocht langs de kust van Halmaheira door Straat Patientie, langs de Westkust van Groot-Waygeeuw en voorbij het eiland Moretay, de Talautsche eilanden, Sangier enz. langs de Zuidkust van Magindanao naar de Hoek van ....? bewesten het eiland Groot-Sangier, Siauw, Tagulanda en Bejaer tot onder de Noordkust van Celebes.

Op dezen kruistocht was hun niets bijzonders bejegend, dan de nieuw vier ontdekte eilandjes die op geen kaart bekend stonden, en waarvan een verkenkaartje met copie hunner journalen naar Batavia werden overgezonden. Die eilandjes waren slechts kleine heuveltjes waarop geen specerijboomen konden groeien en lagen tusschen Popa en Gagy.

Doch noch dat kaartje, noch de journalen dezer schepen op dien kruistocht gehouden, bevinden zich in het Archief der O. I. C. op het Rijks-Archief.

LEUPE. 